\title{
Description of the male of Eburella pinima Martins and notes on the geographical distribution of Eburodacrys aenigma Galileo \& Martins and Eburodacrys lanei Zajciw (Coleoptera, Cerambycidae)
}

\author{
Juan Pablo Botero \\ Departamento de Entomologia, Museu Nacional, Universidade Federal do Rio de Janeiro, UFRJ, Quinta da Boa Vista, São Cristovão, \\ 20940-040, Rio de Janeiro-RJ, Brazil..jp_bot@yahoo.com
}

\begin{abstract}
Description of the male of Eburella pinima Martins and notes on the geographical distribution of Eburodacrys aenigma Galileo \& Martins and Eburodacrys lanei Zajciw (Coleoptera, Cerambycidae). The male of Eburella pinima Martins, 1997 is described and illustrated for the first time. Information on Eburodacrys aenigma Galileo \& Martins, 2006, previously known only from the female holotype, which lacked locality label, is herein complemented. This species is recorded from Brazil and the male is depicted for the first time. The geographical distribution of Eburodacrys lanei Zajciw, 1958 is further restricted here as some previous records are confirmed to result from misidentifications of E. aenigma.
\end{abstract}

KEYWORDS. Cerambycinae; Eburiini; Insecta; Neotropical Region.

The tribe Eburiini includes 22 genera (Monné 2012) and 253 species, all with geographical distribution restricted to the Americas. This contribution adds to our knowledge of the tribe, describing the unknown male of a species of Eburella and complementing the information on the geographical distribution of two species of Eburodacrys.

All the material examined is deposited in the Museu Nacional, Universidade Federal do Rio de Janeiro, RJ, Brazil (MNRJ).

\section{Eburella pinima Martins, 1997}

(Figs. 1-2)

Eburella pinima Martins, 1997: 67, fig. 9; 1999: 151; Galileo \& Martins, 2006: 181

Male. Integument reddish-orange. Head with fine and sparse punctures. Upper eye lobes well separated, distance between them about $4 \mathrm{x}$ a lobe width. Antennae surpassing elytral apices at antennomere VII. Scape subcylindrical, pedicellum, antennomere III-IV and basal half of antennomere $\mathrm{V}$ with long and erect hairs on ventral face. Scape slightly shorter than one-half of antennomere III, IV one-seventh shorter than antennomere III, IV-VII subequal in length, VIII$\mathrm{X}$ gradually decreasing in length, X-XI subequal in length.

Prothorax elongate, without lateral spines. Pronotum almost glabrous, with fine and sparse punctures; laterally with long, erect and sparse hairs. Prosternum with slight transverse depression. Prosternal process about one-fifth as wide as procoxal cavity. Mesosternal process as wide as mesocoxal cavity.
Elytra elongate, $4 \mathrm{x}$ humeral width; anterior half finely and uniformly punctate, posterior half with sparse punctures decreasing to apex, apex smooth. Apices with external spine and internal tooth.

Meso- and metafemora with acute internal spine. Mesoand metatarsomere I as long as II-III together. Urosternites without sexual pubescence (Fig. 2). Apex of urosternite V emarginated.

Measurements, in mm. Total length, 9.3; prothorax length, 1.7; prothorax width, 1.3; elytral length, 6.7 ; humeral width, 1.8 .

Examined material. BOLIVIA, Santa Cruz: Amboro (Rd above Achira campo 5-5, 800'), one male, 9-11.X.2004, Wappes \& Morris leg.

Remarks. The genus Eburella was described by Monné \& Martins (1973) for a single species, E. pumicosa. Currently, the genus has three known species, males of two of which are known, E. pumicosa and E. longicollis Martins \& Galileo, 1999. In E. pumicosa, the males bear sexual pubescence in the urosternites I-IV (Fig. 3), whereas these are glabrous in males of E. longicollis and E. pinima (Fig. 2).

\section{Eburodacrys aenigma Galileo \& Martins, 2006}

$$
\text { (Fig. 4) }
$$

\section{Eburodacrys aenigma Galileo \& Martins, 2006: 181, fig. 3.} Eburodacrys lanei; Monné, 1990: 170 (misidentification).

Galileo \& Martins (2006) described Eburodacrys aenigma based on a single female which was not accompanied by any locality label (inspiration for the epithet "aenigma"). Before 

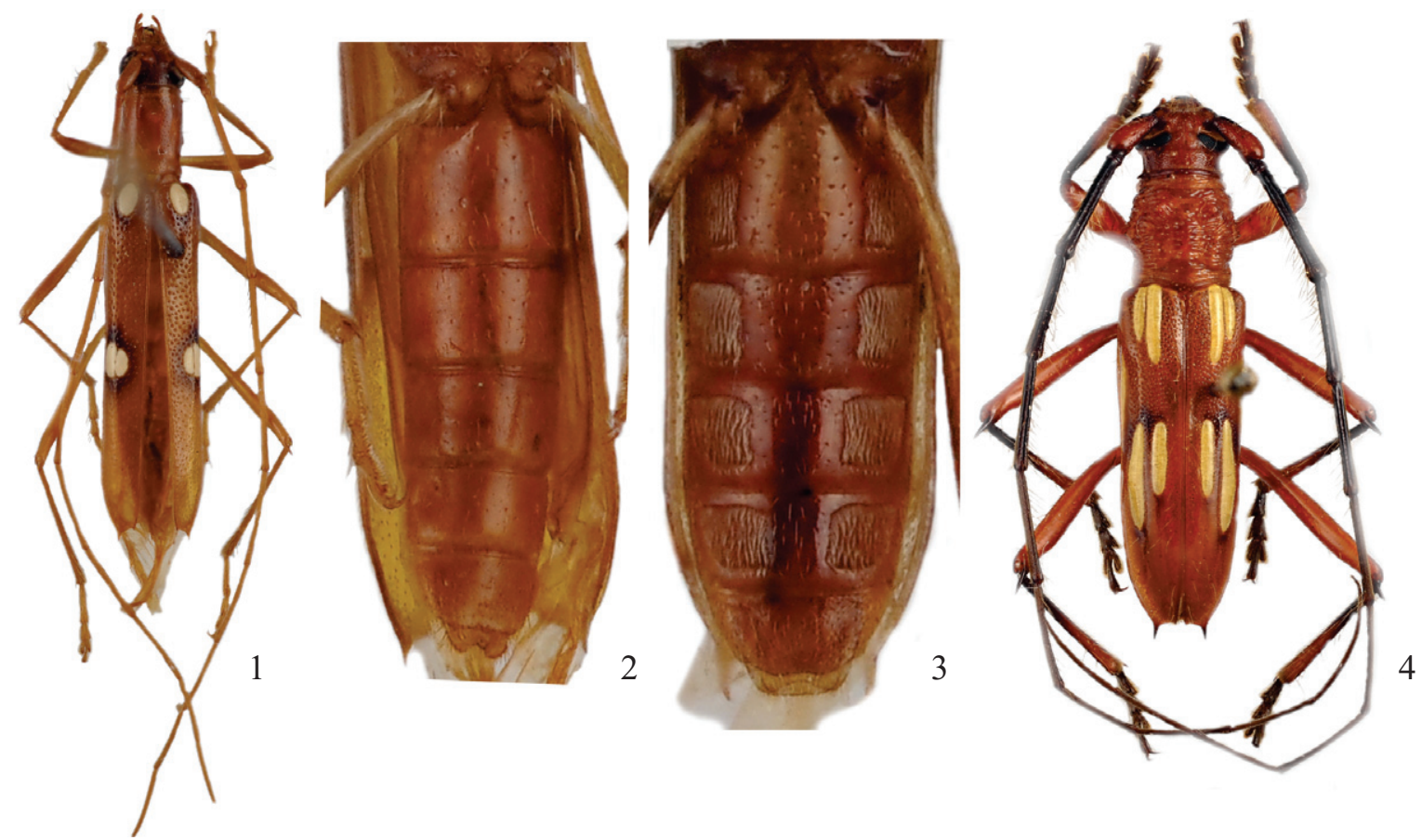

Figs. 1-4. 1-2, Eburella pinima, 1, male, 2, detail of urosternites; 3, Eburella pumicosa, detail of urosternites; 4, Eburodacrys aenigma, male.

this work, the holotype was the only specimen known for this species and its distribution remained unknown. This species is here recorded from the Brazilian states of Rondônia and Mato Grosso, and the male is illustrated for the first time (Fig. 4). In this species, the antennae surpass the elytral apices at segments VII in males and at segment IX or X in females.

Distribution. Brazil (Rondônia; Mato Grosso).

Examined material. BRAZIL, Rondônia: Ariquemes, one male, VIII.1980, B. Silva leg.; Ouro Preto do Oeste, one female, X.1980, B. Silva leg.; 2 males, X.1983, O. Roppa, J. Becker \& B. Silva leg.; Pimenta Bueno, one female, X.1986, O. Roppa, P. Magno \& J. Becker leg.; Mato Grosso: Barra do Bugres, one male, X.1984, B. Silva leg.

\section{Eburodacrys lanei Zajciw, 1958}

Eburodacrys lanei Zajciw, 1958: 233; Napp \& Martins, 1980: 84; Martins, 1997: 61; 1999: 284; Julio et al., 2000: 11.

Monné (1990) erroneously reported Eburodacrys lanei for Brazil (Rondônia and Mato Grosso). This was determined upon recent study of the specimens that yielded these records, which revealed that they actually belong to E. aenigma (sex association previously unknown). Consequently, the geographical distribution of $E$. lanei is here restricted to Peru and Bolivia.

Distribution. Peru (Junin) and Bolivia (Beni; La Paz).

\section{ACKNOWLEDGMENTS.}

I am grateful to Dr. Miguel A. Monné (MNRJ) for providing helpful comments about the manuscript, to BSc. Ricardo Botero Trujillo for reviewing the English text, and to James E. Wappes (American Coleoptera Museum, Texas) for the donation of the specimen of Eburella pinima.

\section{REFERENCES}

Galileo, M.H.M. \& Martins, U.R. 2006. Notas e descrições em Eburiini (Coleoptera, Cerambycidae). Iheringia, Série Zoologia, 96: 179-184. Julio, C.E.A., Giorgi, J.A. \& Monné, M.A. 2000. Os tipos primários de Cerambycidae (Coleoptera) da coleção do Museu Nacional - Rio de Janeiro. Publicações Avulsas do Museu Nacional 84: 1-54.

Martins, U.R. 1997. Contribuições para uma revisão das espécies sul-americanas da tribo Eburiini (Coleoptera, Cerambycidae). Revista Brasileira de Entomologia 41: 57-83.

Martins, U.R. 1999. Tribo Eburiini, p. 119-391. In: Martins, U.R. (org.) Cerambycidae Sul-americanos (Coleoptera) Taxonomia. Vol. 3. São Paulo, Sociedade Brasileira de Entomologia, 418 p.

Monné, M.A. 1990. Lista sistemática dos Cerambycidae (Coleoptera) da região da Chapada de Guimarães, p. 122-123. In: Levantamento faunístico. Levantamento faunístico da área de influência da BR364 (Cuiabá-Porto Velho). Programa Polonoroeste. Brasília, Conselho Nacional de Desenvolvimento Científico e Tecnológico, 236 p.

Monné, M.A. \& Martins, U.R. 1973. Notas e descrições em Eburiini (Coleoptera, Cerambycidae). Papéis Avulsos de Zoologia 27: 145-155.

Monné, M.A. 2012. Catalogue of the type-species of the genera of the Cerambycidae, Disteniidae, Oxypeltidae and Vesperidae (Coleoptera) of the Neotropical Region. Zootaxa 3213: 1-183.

Napp, D.S. \& Martins, U.R. 1980. Sinonímias, descrições e chave para espécies de Eburodacrys White, 1853 (Coleoptera, Cerambycidae). Papéis Avulsos de Zoologia 33: 77-97.

Zajciw, D. 1958. Novos longicórneos neotrópicos (Col., Cerambycidae). Revista Brasileira de Entomologia 8: 233-262.

Received 19 July 2013; 29 September 2013

Associate Editor: Marcela L. Monné 